\title{
Experimental Study of Moment Method for Undergraduates in Electromagnetic
}

\author{
N. F. O. Serteller \\ Department of Electrical Education, Marmara University, \\ Istanbul,Turkey,e-mail:fserteller@marmara.edu.tr
}

\section{A. G. Ak}

Electronics Technology Program of VSTS, Marmara University, Istanbul,Turkey,e-mail:aycaak@marmara.edu.tr

\section{G. Kocyigit}

Department of Electonics \& Communications Engineering, Trakya University, Istanbul, Turkey, e-mail:gkocyigit@gmail.com

\section{T. C. Akinci}

Department of Electrical \& Electronics Engineering, Kirklareli University, Kirklareli,Turkey,e-mail:cetinakinci@hotmail.com

\section{Introduction}

The use of MOM in Electromagnetic (EM) has become popular since the work of Richmond's studies in 1965. The method has been successfully applied to wide variety of EM problems of practical interest such as radiation due to thin wire elements, transmission lines and antenna application [1-5].

Various computational techniques have been developed over the past three decades to solve electromagnetic problems. MOM is the one of these [1]. The same problem may be solved using variety of methods, like finite element method (FEM), finite difference method (FD), Monte Carlo method (MCM) and variation methods (VM) and so on. But some cases MOM have an advantage over them. These methods have advantage and disadvantages depending on the application and on the whole the problem of choosing the optimal method for numerical modelling remains open. In the numerical techniques: FD and MOM are conceptually simple; while the finite difference method is used in solving differential equations, the moment method is commonly used in solving integral equation. However MOM is more suitable for parallels surface application.

The main aim here is to convey the methods of computational electromagnetic, but to give deeper insight into electromagnetic phenomena by presenting the examples and software programming (See Appendix) and also by giving the curriculum which may be helpful to learn quickly the basic concept of numerical solutions. The introduced research is prepared to solve $2 \mathrm{D}$ parallel plate conductor's field density distribution and its capacitance by using MOM method, consequently comparing the numerical results with the experimental results. In fact, this paper allows students to define structures of MOM and use of the computer software for numerical methods $[6,7]$. This paper provides to students to solve more complex numerical methods.

\section{Mathematical Equation of the System}

Electromagnetic problems can be stated in terms of an inhomogeneous equation

$$
L \phi=g \text {, }
$$

where $\mathrm{L}$ is the operator, which may be differential or integral or integro-differential, $g$ is the known excitation or source function and $\varphi$ is the unknown function to be determined.

Representing the unknown function $\varphi$ by the series of expansion

$$
\varphi=\sum_{k=1}^{\infty} \alpha_{k} \varphi_{k},
$$

where the $\varphi_{k}$ is the coefficient, to be determined and the series of function $\alpha_{k}$ in the domain $\mathrm{L}$ are called basis or expansion functions. With the finite $\mathrm{N}$ and substituting (2) into (1), under linearity, provides that 


$$
\sum_{k=1}^{N} \alpha_{k}\left(L \varphi_{k}\right) \cong g .
$$

A set of weighting function $\omega$ is defined by arbitrary choice and the inner product, taken to be the integral over the interval of the product of function in accord with Equation (3) is redesign with $\omega_{m}$

$$
\sum_{k=1}^{N} \alpha_{k}\left\langle L \phi_{k}, \omega_{m}\right\rangle \approx\left\langle g, \omega_{m}\right\rangle .
$$

Progressing $m=1,2,3 \ldots \ldots \ldots \ldots, N$ yield a set of equation which can be expressed in matrix form as

$$
\tilde{L}\left|\alpha_{k}\right\rangle \cong\left|g_{m}\right\rangle
$$

where $\tilde{L}$ is $\mathrm{N} \times \mathrm{N}$ matrix and $\left|\alpha_{k}\right\rangle,\left|g_{m}\right\rangle$ are $\mathrm{N} \times 1$ column vectors so the coefficients required for a solution available from the operation

$$
\left|\alpha_{k}\right\rangle \cong L^{-1}\left|g_{m}\right\rangle
$$

For electromagnetic Poisson's equation, transforms to following equation. (Eq. (7))

$$
[Q]=[A]^{-1}[B]
$$

where $Q$ is the surface charge density, $A^{-1}$ is the coefficient matrix's inverse and B is the known boundary values with the reference to Fig.1.

\section{Educational Curriculum}

Problems that an undergraduate encounters in the first course in electromagnet theory are typically highly idealized and soon become mathematically intractable. The required computer sophistication needed to obtain a pictorial solution to get a simple practical problem. The purpose of the paper is to take a somewhat more realistic electrostatics problem in order to show that it can be easily treated using with suitable software, as it is used here MATHEMATICA. We consider following essential elements in teaching the subject of computational electromagnetic:

- Students must be involved in developing the algorithms without becoming bogged down complex programming such as matrix inversion and data visualization;

- Students must learn to verify their codes using experimental studies. Their solution must not only be verified by $2 \mathrm{D}$ plots or graphs but also by experimental works which can be observed by students;

- Excessive assessment of simple or trivial exercises is not desirable. Individualized projects following no assessed, non compulsory, learning workshops have generated considerable student enthusiasm for the subject.

Integrated programming language combines attractive, easily produced graphics with powerful support for mathematical modelling. These languages support both a high level programming languages and packages for symbolic or algebraic manipulation, matrix operations and visualization. Examples for such products which are commonly used are Maple, MATHEMATICA, MATLAB and MathCAD. We use MATHEMATICA based integrated programming language for this subject with all of its graphical capabilities (see Appendix). In particular, we pose and then solve the problem for the charge density distribution and the evaluation of the voltage within the capacitor. At least one lesson in bachelor degree must be emphasized to the students. This kind of courses had been thought in Griffith University and the degreed students have been recognized with their highly improved computational skills by employers $[8,9]$.

\section{Procedure for Experimental and MOM Results}

With the reference to Fig. 1 the square- area of capacitor plate is totally subdivided into $3 \times \mathrm{N} \times \mathrm{N}$ subareas. The charge in particular sub area $\Delta Q$ is assumed to be centered and have value

$$
\Delta Q=\rho\left(\frac{(\text { area })^{2}}{N^{2}}\right)
$$

where $\rho$ is the charge density in that particular sub-area. The potential at the center of sub-area due to charge $\Delta Q$ can be computed specific formula of $\mathrm{V}$ :

$$
V(h)=\frac{1}{4 \pi \varepsilon_{0} \varepsilon_{r}} \frac{\Delta Q(h)}{|h|},
$$

$\varepsilon_{0} \varepsilon_{r}$ is orderly, air and material dielectric coefficients.

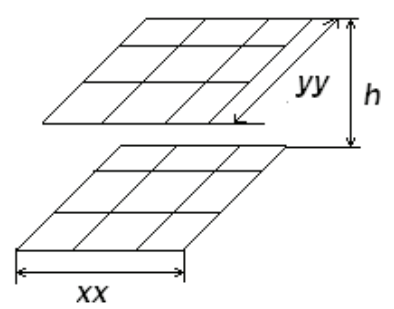

Fig. 1. A parallel plate capacitor that is divided into $3 \times \mathrm{N} \times \mathrm{N}=18$ sub-sections

Using Eq. (7), adding the known boundary conditions which are potential differences the system is solved to find out unknowns [8]. The unknown quantities in this case would be the actual charge distribution that exists on the plate. With the specified values for the voltage (potential difference) between the two plates being constant, the learners can easily calculate the capacitance between the two plates. The thickness of the materials differs from one to the other. The flow of the program of interest area solution is given in Appendix and graph result is thought to support the experimental results see in Fig. 3 and 4.

Block representation of the experimental setup is shown in Fig 2. Experimental results are given in comparison in Table 1. 


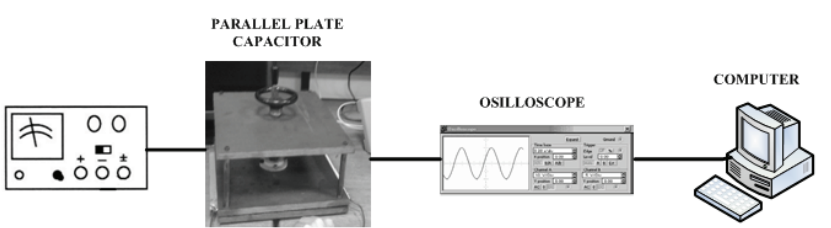

Fig. 2. Block representation of the experimental setup

Table 1. Comparison Experimental results with MOM developed in Mathematica software

\begin{tabular}{|c|c|c|c|}
\hline Components & $\boldsymbol{\varepsilon r}$ & $\begin{array}{c}\text { Experimental } \\
\text { results(pF) }\end{array}$ & $\begin{array}{c}\text { Numeric } \\
\text { results(pF) }\end{array}$ \\
\hline Water & 80 & 220 & 227.486 \\
\hline $\begin{array}{c}\text { Nylon } \\
\text { (Thick layer) }\end{array}$ & 8 & 5.6 & 5.86 \\
\hline Paper & 7 & 13.2 & 13.75 \\
\hline
\end{tabular}

Charging and discharging graph of the plate capacitor obtained experiments is shown in Fig 3., graph of Rho versus plates area obtained from developed program is given in Fig. 4.

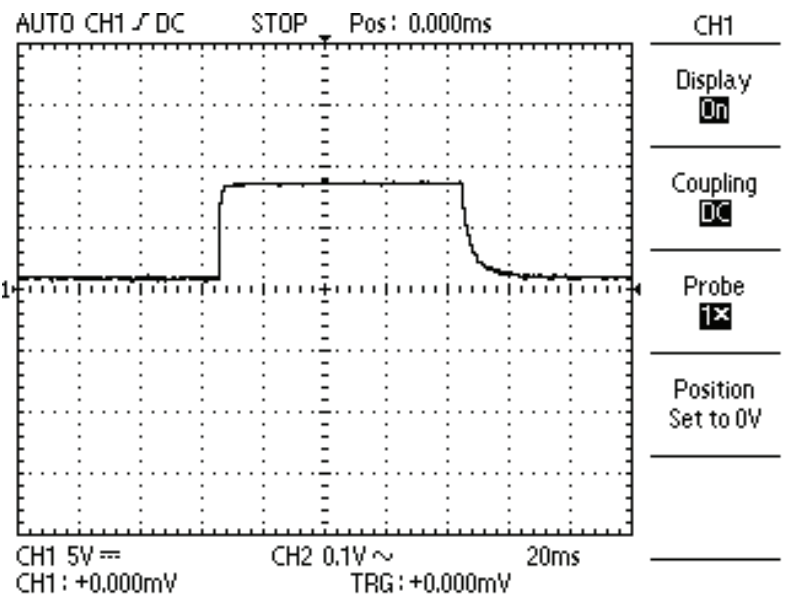

Fig. 3. Charging and discharging graph of the plate capacitor

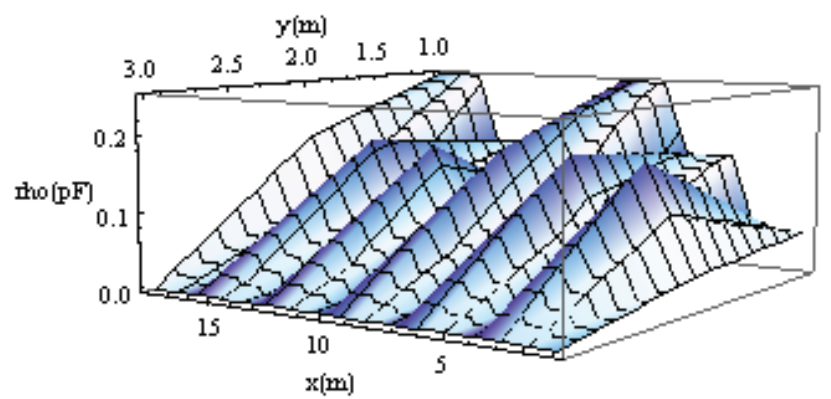

Fig. 4. Graph of Rho $(\rho)$ versus plates area

\section{Conclusions}

The experimental results can be quantitatively compared with theoretical models. In particular, using MOM technique, the results have been obtained in straightforward manner. In fact, complex and arbitrary numerical methods can be understandable by students, if the experimental and numerical method both is implemented to interested area. In this paper, 2D parallel plate conductor's field density distribution and calculation of its capacitance by using MOM method are presented to define structures of MOM and use of the computer

software for numerical methods to encourage the students to study further examples. The results of theoretical calculations are in good agreement with the experimental results.

\section{Appendix}

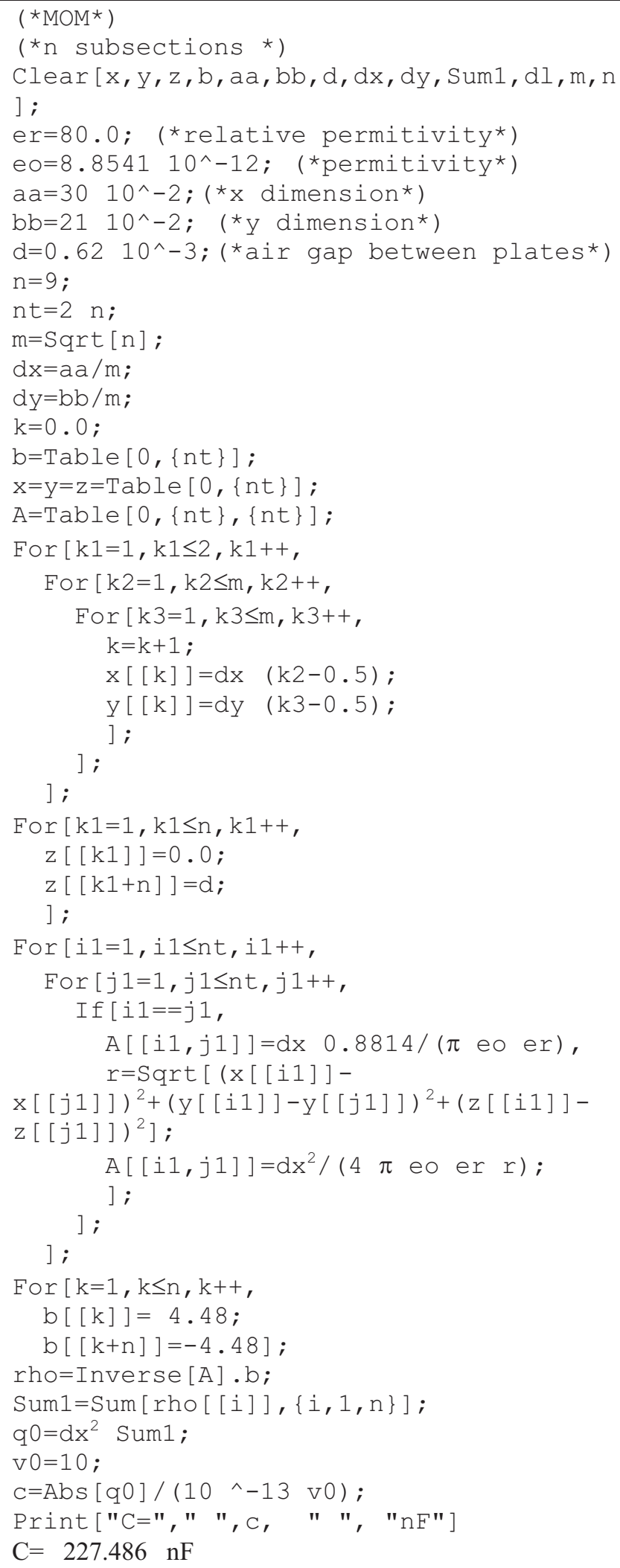




\section{References}

1. Sadıku M. N. O. Comparison of Numerical Methods for Computing Electromagnetic Field // Conference proceedings of IEEE SOUTHEASTCON, 1990. - No.1. -P. 42-47.

2. Lonngren K. E., Schwartz P. V., Bai Er-W. Device Phiysics Using Method of Moment // IEEE Transaction on Education, 1998. - Vol.41. - No. 2. - P.112-115.

3. Schuneman N., Fisher S. E. Michielssen E. Anten Net: A Web based Method of Methods Solver for Antenna Education // IEEE Antennas and propagation Society International Symposium, 2000. - No. 1. - P. 48-51.

4. Wheles W. P., Wurtz L. T. Introducing Undergrads to the Moment Method // IEEE Transaction on Education, 1995. No. 38. - P. 385-390.

5. Malisauskas V., Sledevic T. Investigation of the Electromagnetic Fields in Gyrotropic Waveguides // Electronics and Electrical Engineering. - Kaunas: Technologija, 2011. - No. 1(107). - P. 29-32.
6. Bartkevičius S., Novickij J. The Investigation of Magnetic Field Distribution of Dual Coil Pulsed Magnet // Electronics and Electrical Engineering. - Kaunas: Technologija, 2009. No. 4(92). - P. 23-26.

7. Sadiku M. O. Elements of Electromagnetics, $3^{\text {rd }}$ ed. - New York: Oxford Press, 2001. - 694 p.

8. Lu J. Theil D. Computational and visual Electromagnetics Using an Integrated programming Language for Undergraduate Engineering Students // IEEE Transaction on Magnetics, 2000. -No. 36(4). - P. 1000-1003.

9. Warnick K. F., Selfridge R. H., Arnold D. V. Teaching Electromagnet Field Theory Using Differential Forms // IEEE Transaction on Education, 1997. - No. 40(1). - P. 53-68.

N. F. O. Serteller, A. G. Ak, G. Koçyigit, T. Ç. Akıncı. Experimental Study of Moment Method for Undergraduates in Electromagnetic // Electronics and Electrical Engineering. - Kaunas: Technologija, 2011. - No. 3(109). - P. 115-118.

The experimental study and Moment Method with is programmed in Mathematica are presented here to facilitate introductory instruction on numerical methods for undergraduate electrical education students. The Method of Moments (MOM) is introduced at the beginning level to prepare students for subsequent advanced topics in complex matrix method and linear vector space theory. The study is carried out with parallel plate capacitor. The different capacitor (dielectric) materials are tried and coincidental program of MOM are studied. Ill. 4, bibl. 9, tabl. 1 (in English; abstracts in English and Lithuanian).

N. F. O. Serteller, A. G. Ak, G. Kocyigit, T. C. Akinci. Momento metodo taikymas elektromagnetizmo teorijos studijose // Elektronika ir elektrotechnika. - Kaunas: Technologija, 2011. - Nr. 3(109). - P. 115-118.

Elektros inžinerijos studijų programą studijuojantiems studentams skirtas momento metodas yra pateiktas programų pakete Mathematica kartu su kitais skaitmeniniais metodais. Metodas taikomas nuo žemiausiojo lygmens, skirto supažindinti su didele dalimi pagrindinès informacijos, taip pat ir matricos metodais ir vektorinès erdvės teorija. Tyrimas atliekamas taikant lygiagrečiai sujungtus kondensatoriaus elektrodus. Tiriami ịvairaus tipo dielektrikai. Il. 4, bibl. 9, lent. 1 (anglų kalba; santraukos anglų ir lietuvių k.). 